\title{
AIDS awareness and attitudes among Yemeni young people living in high-risk areas
}

\author{
A.W. Al-Serouri, M. Anaam, ${ }^{2}$ B. Al-Iryani, ${ }^{3}$ A. Al Deram ${ }^{4}$ and S. Ramaroson ${ }^{3}$
}

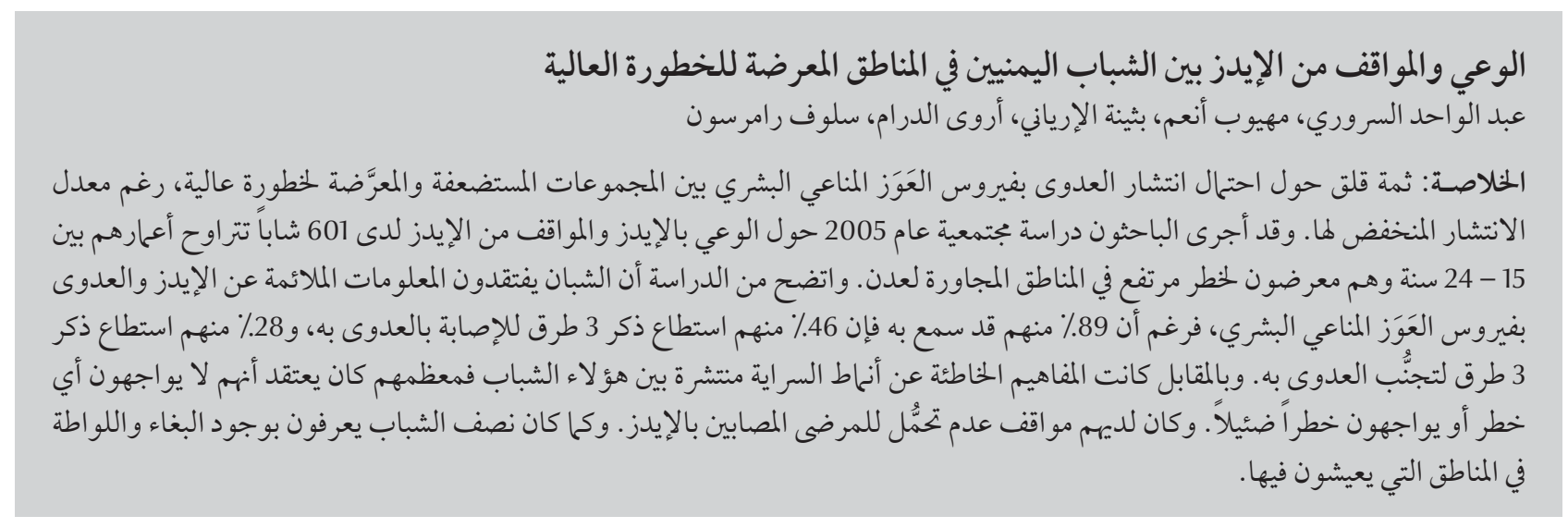

ABSTRACT Despite the low rate of infection in Yemen, there are concerns about the possible spread of HIV among high-risk and vulnerable groups. A community-based study was made in 2005 of AIDS awareness and attitudes among 601 young people aged 15-24 years from low-income, high-risk neighbourhoods in Aden. Young people lacked proper information about HIV/AIDS. Although 89\% had heard of AIDS, fewer (46\%) could name 3 ways of transmission or 3 ways to avoid infection (28\%). Misconceptions about modes of transmissions were prevalent and many young people believed that they faced little or no risk. There were intolerant attitudes towards AIDS patients. About half the young people knew that prostitution and homosexuality existed in their area.

\section{Sensibilisation au sida et attitudes des jeunes Yéménites vivant dans des quartiers à haut risque}

RÉSUMÉ Malgré le faible taux d'infection au Yémen, la propagation possible du VIH parmi les groupes à haut risque et vulnérables suscite des préoccupations. Une étude communautaire, sur la sensibilisation au sida et les attitudes parmi 601 jeunes âgés de 15 à 24 ans issus des quartiers à haut risque d'Aden, caractérisés par de faibles revenus, a été conduite en 2005. Les jeunes gens manquaient d'informations correctes sur le VIH/sida. Bien que $89 \%$ d'entre eux aient entendu parler du sida, ils étaient nettement moins nombreux (46\%) à pouvoir citer trois modes de transmission ou trois moyens d'éviter l'infection (28\%). Les idées reçues sur le mode de transmission étaient fréquentes et de nombreux jeunes étaient persuadés de courir très peu de risques, voire aucun. Des attitudes intolérantes vis-à-vis des malades du sida ont été observées. Environ la moitié des jeunes savaient que la prostitution et l'homosexualité existaient dans leur quartier. 


\section{Introduction}

Young people aged 15-24 years remain at the centre of the global HIV/AIDS pandemic in terms of transmission and vulnerability [1]. Nevertheless, young people present an opportunity to halt the spread of the epidemic [2]; in countries where the spread of HIV/AIDS is subsiding or declining, such as Thailand and Uganda, it is primarily because young men and women are being given the knowledge, tools and services to adopt safe behaviours [2]. The United Nations has resolved that by 2010 at least $95 \%$ of young men and women aged 15-24 years should have access to the information, education and services necessary to develop the life skills required to reduce their vulnerability to HIV infection [3].

Yemen is still considered a country with a low rate of HIV infection, with an accumulated number of registered cases by the year 2004 of 1549 and an estimated number of 15000 [4]. Nevertheless, recent situation analyses cited conditions that could facilitate the spread of HIV among high-risk and vulnerable groups as well as the population in general $[5,6]$. These include: high rates of illiteracy, low quality and limited access to health care services, high prevalence of sexually transmitted infections, population movements to and from countries with high HIV infection rates and inadequate public awareness. The HIV/AIDS national strategy, endorsed in 2002, sets the framework for effective and coordinated interventions for the prevention and control of HIV/AIDS [7].

Research data on young people's knowledge about how HIV is transmitted and their perspectives on whether HIV is an issue that is directly relevant to them are scarce in Yemen [8]. This paper presents the findings of a household survey that aimed to establish a clear understanding of young people's knowledge about the transmission of
HIV/AIDS and self-protection from infection and their attitudes towards people living with HIV and AIDS. The findings will provide baseline indicators to help design and evaluate a package of integrated interventions supported by the United Nations Children's Fund (UNICEF).

\section{Methods}

The present study, conducted from March to September 2005, was a community-based, cross-sectional study of young people aged 15-24years living in 4 districts in the city of Aden, the economic capital and the main port of Yemen.

\section{Study area and sample}

The 4 areas were Abdul Qaui and Al Memdarah (inhabited mainly by Yemeni citizens), Al Basateen (inhabited mainly by Somali refugees) and Al Sesaban (inhabited by Yemeni marginalized citizens known as al-akhdam). Al-akhdam, who live in isolation from the rest of society, are stereotyped as dishonourable, immoral, dependent and dirty. They exist at the bottom of the class system of Yemeni society and are forbidden to socialize or intermarry with any other classes. Although a growing number of al-akhdam children have started going to school, large numbers continue to be unenrolled or drop out soon after joining because of financial constraints [9]. These 4 low-income neighbourhoods are recognized as high risk due to the large numbers of commercial sex workers living there and because they represent transit hubs for migrant populations coming from the Horn of Africa, where the prevalence of HIV/AIDS is higher than in Yemen [10].

The minimum sample size- - keeping the expected parameter (proportion of young people with satisfactory knowledge) at 0.5 and with an acceptable deviation of 0.1 on each side at an alpha error of 0.05 (2-tailed) (i.e. acceptable $95 \%$ confidence limit 0.4 to 0.6) - was estimated as 100 for each of the 4 communities. Due to potential nonresponse, a much larger sample size of 601 was studied.

The sampling unit (the household) was selected by systematic sampling methods. Initial mapping by the study team helped to determine the sampling frame. According to the area size, each area was divided into 5-10 sections and each section was divided into 5 to 10 blocks with each block comprising 25-40 households. First, 2 to 4 sections were selected randomly (by random tables) from each area and then similarly 4-7 blocks from each section. Finally, 20-25 households were selected from each block by a systematic sampling method where the sampling interval was calculated by dividing the total number of houses in the block by the number of houses in the sample. The number of the first house in the sample was selected from simple random tables and within the sampling interval. The next house was determined by adding the sampling interval to the previous house number in the sample and so on.

Only households containing males and/or females aged between 15 and 24 years were eligible for inclusion in the sample. If a household had no members in the target age group, the interviewer continued sampling as previously described until the required sample size was achieved. A maximum of 2 eligible persons were interviewed from each household. During pilot studies we found that for cultural reasons the youngest females were less likely to be allowed to participate by the head of the household. Even when permitted, we found that the females lagged far behind their male peers in exposure to knowledge in general and to HIV/ AIDS in particular and rarely responded to questions. They were also more likely to withdraw during the interview. Therefore, the study team was obliged 
to use the following selection criteria when there were more than 2 eligible individuals at a household: if more than 2 eligible persons but only 1 female, interview that female and the youngest male; if more than 2 eligible persons but only 1 male, interview that male and the oldest female; if more than 2 eligible persons at a household and all were males, interview the oldest and youngest males; if more than 2 eligible persons at a household and all were females, interview the 2 oldest females; if more than 2 eligible persons at a household and of both sexes, interview the oldest female and the youngest male.

\section{Questionnaire}

The questionnaire was adapted from the core interview schedule on AIDS knowledge, attitudes, beliefand practices of the Social and Behavioural Research Unit of the World Health Organization (WHO) Global Programme on AIDS. The Arabic version of this questionnaire was prepared by the WHO Regional Office for the Eastern Mediterranean and was previously tested in the HIV/ AIDS Situation and Needs Assessment Study in Yemen in 2001; it proved to be acceptable and reliable in the Yemeni context [5]. Additional questions were extracted from the UNICEF Multiple Indicator Cluster Survey questionnaire [11]. The questions were a mix of closed- and open-ended questions that covered sociodemographic characteristics, knowledge, attitudes and practices. The draft questionnaire was piloted on 25 young people and was refined accordingly. The subjects of the pilot study were not included in the final analysis.

The questionnaire was administered by qualified male and female fieldworkers. They were trained in administration of the questionnaire by the first author, who also supervised the entire conduct of the study. Male respondents were interviewed by male fieldworkers and femalerespondents byfemalefieldworkers. As far as possible, interviews were conducted in private in a quiet room or area in the household. Respondents were informed of the scope of the study and were assured of full confidentiality. After initial rapport-building, the questions were asked in a personal faceto-face interview. Although about 15\% of the eligible young people refused to participate at the beginnning, this dropped to only $6 \%$ after explanation.

\section{Data analysis}

All collected data were coded, entered and analysed using SPSS, version 13.0.

\section{Results}

A total of 601 young people aged 15-24 years participated in the study. Table 1 shows the demographic characteristics of the study sample.

\section{General awareness about HIV infection/AIDS}

Basic awareness - as measured by responses to the question whether they had ever heard about AIDS - was generally high (89\%) (Table 2). Such knowledge was significantly related to sex, as significantly more males had heard about AIDS than had females

\begin{tabular}{|c|c|c|}
\hline Characteristic & No. & $\%$ \\
\hline \multicolumn{3}{|l|}{ Sex } \\
\hline Female & 342 & 56.9 \\
\hline Male & 259 & 43.1 \\
\hline \multicolumn{3}{|l|}{ Education } \\
\hline Illiterate & 137 & 22.8 \\
\hline Read and write & 50 & 8.3 \\
\hline Basic & 247 & 41.1 \\
\hline Secondary & 140 & 23.3 \\
\hline Diploma & 9 & 1.5 \\
\hline University & 18 & 3.0 \\
\hline \multicolumn{3}{|l|}{ Marital status } \\
\hline Single & 453 & 76.0 \\
\hline Married & 136 & 22.8 \\
\hline Widowed & 1 & 0.2 \\
\hline Divorced & 6 & 1.0 \\
\hline \multicolumn{3}{|l|}{ Occupation } \\
\hline Student & 195 & 32.4 \\
\hline Housewife & 171 & 28.5 \\
\hline Unemployed & 145 & 24.1 \\
\hline Salaried employee & 32 & 5.3 \\
\hline Skilled labourer & 21 & 3.5 \\
\hline Non-skilled labourer & 23 & 3.8 \\
\hline Other & 14 & 2.3 \\
\hline \multicolumn{3}{|l|}{ Social category } \\
\hline Yemeni citizen & 373 & 62.0 \\
\hline Yemeni citizen: marginalized ${ }^{a}$ & 156 & 26.0 \\
\hline Refugee & 66 & 11.0 \\
\hline Yemeni citizen: returnee ${ }^{b}$ & 6 & 1.0 \\
\hline
\end{tabular}

${ }^{a}$ Al-akhdam.

${ }^{b}$ Living/working aboard and evacuated after Gulf war. 


\begin{tabular}{|c|c|c|c|c|c|c|}
\hline \multirow[t]{2}{*}{ Item } & \multicolumn{2}{|c|}{ Yes } & \multicolumn{2}{|c|}{ No } & \multicolumn{2}{|c|}{ Don't know } \\
\hline & No. & $\%$ & No. & $\%$ & No. & $\%$ \\
\hline Had heard about AIDS & 530 & 89 & 68 & 11 & - & - \\
\hline Knew at least 3 correct modes of AIDS transmission & 239 & 45 & 291 & 55 & - & - \\
\hline Knew at least 3 correct modes of AIDS prevention & 148 & 28 & 382 & 72 & - & - \\
\hline AIDS causative agent is a virus & 197 & 37 & 64 & 12 & 269 & 51 \\
\hline AIDS patient may have no symptoms or signs & 186 & 35 & 248 & 47 & 96 & 18 \\
\hline AIDS is an infectious disease & 488 & 92 & 16 & 3 & 27 & 5 \\
\hline AIDS is a curable disease & 88 & 17 & 349 & 65 & 94 & 18 \\
\hline Condoms are an effective preventive measure & 152 & 29 & 148 & 28 & 232 & 43 \\
\hline
\end{tabular}

$n=$ total sample; data are missing for some items.

$(94 \%$ versus $84 \%)\left(\chi^{2}=13.8, P<0.001\right)$ [odds ratio $(\mathrm{OR})=2.1,95 \%$ confidence interval (CI): 1.3-3.3]. Illiteracy was another significant determinant of basic awareness about AIDS (24\% versus $8 \%)\left(\chi^{2}=28.8, P<0.001\right)(\mathrm{OR}=3.2$, 95\% CI: 2.1-4.9).

However, when HIV/AIDS awareness was measured by knowledge of at least 3 correct modes of AIDS transmission and 3 correct methods of AIDS prevention, the proportions answering correctly dropped to $45 \%$ and $28 \%$ respectively. Refugees and marginalized people were less likely to know 3 correct modes of transmission or prevention compared with Yemeni citizens (33\%, $41 \%$ and $49 \%$ respectively) $(P<$ $0.05)$. Such knowledge also increased as education level increased (no education $76 \%$ versus highly educated $100 \%)(P$ $<0.001$ ). Only $29 \%$ of the respondents knew that condoms were an effective preventive measure, with a significant sex difference ( $43 \%$ of males versus $16 \%$ of females $)(P<0.0001)$.

\section{Knowledge about modes of transmission}

A large majority of young adults had correct knowledge about the major modes of transmission of HIV, such as sexual intercourse, sharps/instruments, blood transfusions and homosexual contact (Table 3). Nevertheless, there were still important misconceptions as some believed that HIV/AIDS could be acquired through shaking hands and touching (28\%). There was only a small difference in misconceptions of the modes of transmission between males and females. However, knowledge of possible modes of transmission and misconceptions were significantly influenced by social category; a higher percentage of those from marginalized groups (36\%) stated that AIDS could be transmitted by shaking hands and touching compared with 25\% and 26\% among refugees and Yemeni citizens respectively $(P<0.05)$.

\section{Attitudes towards AIDS}

Of the respondents, 94\% stated that AIDS was a serious problem and that it could potentially threaten the country's future (Table 4). Around three-quarters of the sample would be willing to look after relatives who contracted HIV/ AIDS. Nevertheless, there was a common attitude that AIDS patients needed to be isolated and should receive special care in special health settings and specialized staff. A few respondents (1\%) believed there was no need to care for AIDS patients and that they should be killed.

As for voluntary testing and counselling, $86 \%$ of respondents were willing to be tested for HIV/AIDS and $12 \%$ would refuse ( $2 \%$ didn't know) (Table 4). Females, however, were less reluctant to take the test than males ( $8 \%$ versus $15 \%$ would refuse $)(P<0.001)$. Refugees expressed more reluctance to take the HIV test than citizens or marginalized groups (18\%, 12\% and $10 \%$ respectively would refuse $)(P<0.01)$. Half of the respondents who would be willing to take the HIV test (49\%) knew that the test could be taken at a hospital, $24 \%$ said it could be taken in any laboratory, $3 \%$ said it could only be taken at a specialized AIDS centre, while $1 \%$ believed that the test could only be taken abroad and $13 \%$ did not know how or where to take an HIV test.

Respondents thought that the government should take a harsher approach to AIDS patients; $13 \%$ stated that the government should kill AIDS patients, while $18 \%$ of the respondents felt that AIDS patients should be imprisoned and $78 \%$ thought that the government should isolate and quarantine AIDS patients in hospitals away from the rest of the community.

When asked what role the community should play towards people living with AIDS, a small percentage (1\%) suggested that the community should report suspected AIDS/HIV cases to the police. About half of respondents suggested that the community should not allow HIV/AIDS patients to be integrated within society, while the remaining half suggested that the community should provide assistance and 


\begin{tabular}{|c|c|c|c|c|c|c|}
\hline \multirow[t]{2}{*}{ Mode of transmission } & \multicolumn{2}{|c|}{ Yes } & \multicolumn{2}{|c|}{ No } & \multicolumn{2}{|c|}{ Don't know } \\
\hline & No. & $\%$ & No. & $\%$ & No. & $\%$ \\
\hline \multicolumn{7}{|l|}{ Mode of transmission (correct) } \\
\hline Extramarital sex & 506 & 95 & 11 & 2 & 14 & 3 \\
\hline Having sex with an infected person & 508 & 95 & 7 & 1 & 18 & 4 \\
\hline Injections & 499 & 94 & 23 & 4 & 9 & 2 \\
\hline Blood transfusions & 486 & 92 & 17 & 3 & 27 & 5 \\
\hline Sharp blades/instruments & 477 & 89 & 30 & 6 & 26 & 5 \\
\hline Male-to-male sex & 444 & 84 & 31 & 6 & 55 & 10 \\
\hline \multicolumn{7}{|l|}{ Mother-to-child transmission: } \\
\hline During pregnancy & 404 & 76 & 46 & 9 & 81 & 15 \\
\hline During labour & 328 & 62 & 62 & 12 & 141 & 26 \\
\hline During lactation & 343 & 64 & 75 & 14 & 113 & 21 \\
\hline \multicolumn{7}{|l|}{ Mode of transmission (misconceptions) } \\
\hline Mosquitoes/insects & 352 & 67 & 79 & 15 & 97 & 18 \\
\hline Deep kissing & 299 & 56 & 132 & 25 & 102 & 19 \\
\hline Contact with clothes & 263 & 50 & 157 & 30 & 110 & 21 \\
\hline Drinking/eating & 246 & 46 & 73 & 14 & 212 & 40 \\
\hline Swimming pool & 221 & 41 & 134 & 25 & 178 & 33 \\
\hline Contact with bathroom items & 212 & 40 & 189 & 36 & 129 & 24 \\
\hline Touching people & 152 & 28 & 317 & 60 & 63 & 12 \\
\hline
\end{tabular}

$n=$ total sample; data are missing for some items.

be sympathetic towards them. Other suggestions were that infected individuals should divorce their partners (18\%), report to the nearest hospital $(6 \%)$ or that the community should provide financial support to AIDS patients for medicines (2\%).

As far as attitude towards contact with HIV/AIDS patients, $77 \%$ of respondents stated that they were not willing to buy groceries from a person with AIDS. Additionally, 74\% stated that a teacher who is infected with AIDS should not continue teaching.

A majority of the respondents (72\%) strongly believed that the government should take action to prevent the spread of AIDS in the country. The most commonly chosen actions were awareness raising (27\%), prevention of prostitution (24\%), isolation of patients (19\%) and imprisoning AIDS patients (12\%). Other less commonly mentioned actions were checking airports and testing foreigners for HIV/ AIDS (7\%), ensuring blood safety (4\%) and imposing prevention and control measures (12\%).

\section{Perceptions of risk}

As manyas $28 \%$ of respondents believed that there was no possibility whatsoever that they themselves could get infected

\begin{tabular}{|c|c|c|c|c|c|c|}
\hline \multirow[t]{2}{*}{ Item } & \multicolumn{2}{|c|}{ Yes } & \multicolumn{2}{|c|}{ No } & \multicolumn{2}{|c|}{ Don't know } \\
\hline & No. & $\%$ & No. & $\%$ & No. & $\%$ \\
\hline $\begin{array}{l}\text { AIDS is one of the most dangerous and important diseases } \\
\text { facing Yemen }\end{array}$ & 482 & 94 & 11 & 2 & 22 & 4 \\
\hline Willing to look after relatives with AIDS & 415 & 78 & 101 & 19 & 16 & 3 \\
\hline $\begin{array}{l}\text { AIDS patients need to be isolated and cared for at special } \\
\text { AIDS hospital }{ }^{a}\end{array}$ & 415 & 78 & - & - & - & - \\
\hline Willing to buy groceries from a person with AIDS & 111 & 21 & 410 & 77 & 11 & 2 \\
\hline Teacher infected with AIDS should continue teaching & 122 & 23 & 394 & 74 & 16 & 3 \\
\hline Willing to be tested for AIDS & 458 & 86 & 62 & 12 & 13 & 2 \\
\hline
\end{tabular}

a"No" and "Don't know" categories were not applicable.

$n=$ total sample; data are missing for some items. 


\begin{tabular}{|c|c|c|c|c|c|c|}
\hline \multirow[t]{2}{*}{ Item } & \multicolumn{2}{|c|}{ Yes } & \multicolumn{2}{|c|}{ No } & \multicolumn{2}{|c|}{ Don't know } \\
\hline & No. & $\%$ & No. & $\%$ & No. & $\%$ \\
\hline Possibility of getting infected him/herself & 230 & 62 & 149 & 28 & 51 & 10 \\
\hline \multicolumn{7}{|l|}{ Which people are at high risk of AIDS?a } \\
\hline Those who have extramarital sex & 352 & 63 & - & - & - & - \\
\hline Homosexuals & 12 & 2 & - & - & - & - \\
\hline Receivers of infected blood & 4 & 1 & - & - & - & - \\
\hline $\begin{array}{l}\text { Users of contaminated syringes or surgical } \\
\text { instruments }\end{array}$ & 4 & 1 & - & - & - & - \\
\hline Foreigners, especially Somalis & 61 & 12 & - & - & - & - \\
\hline Which people are at low risk of AIDS?a & & & - & - & - & - \\
\hline Those who follow their religion & 149 & 28 & - & - & - & - \\
\hline Those who avoid extramarital sex & 128 & 24 & - & - & - & - \\
\hline Those with a single partner & 71 & 13 & - & - & - & - \\
\hline Those aware about transmission methods & 20 & 4 & - & - & - & - \\
\hline Changed behaviour after knowing about AIDS & 178 & 33 & 323 & 61 & 32 & 6 \\
\hline \multicolumn{7}{|l|}{ Behavioural changes (correct) ${ }^{a}$} \\
\hline Avoiding extramarital sexual relations & 62 & 35 & - & - & - & - \\
\hline Not sharing blades & 44 & 25 & - & - & - & - \\
\hline Keeping away from homosexuality & 34 & 19 & - & - & - & - \\
\hline Not sharing needles & 22 & 12 & - & - & - & - \\
\hline Checking blood before transfusion & 12 & 7 & - & - & - & - \\
\hline \multicolumn{7}{|l|}{ Behavioural changes (incorrect) ${ }^{a}$} \\
\hline Not sharing other's belongings & 19 & 33 & - & - & - & - \\
\hline Avoiding contact with patients & 12 & 7 & - & - & - & - \\
\hline Avoiding crowds in khat sessions & 3 & 2 & - & - & - & - \\
\hline Avoiding swimming pools & 2 & 1 & - & - & - & - \\
\hline Avoiding open foods & 2 & 1 & - & - & - & - \\
\hline
\end{tabular}

aRespondents answered query directly. "No" and "Don't know" categories were not applicable. $n=$ total sample; data are missing for some items.

(Table 5). When asked which people were at high risk of acquiring AIDS, the most common group mentioned was those who had extramarital sex (63\%). Other important risk groups, e.g. homosexuals and receivers of infected blood were mentioned by fewer respondents ( $2 \%$ and $1 \%$ respectively), but $12 \%$ believed that foreigners, especially Somalis, were at high risk. Respondents believed that the people who were at low risk were those who were religious (28\%) and those who avoided extramarital sex (24\%).

Only one-third of the young people mentioned that they had changed their behaviour after knowing about AIDS, e.g. by avoiding extramarital sexual relations (35\%) and not sharing shaving blades/razors (25\%). Some erroneous behavioural changes were mentioned, e.g. not sharing other people's clothes and food utensils (33\%) and avoiding contact with HIV/AIDS patients (7\%).

\section{Occurrence of AIDS cases and risky behaviours in the study area}

More than half of the respondents (59\%) knew that there were potential cases of AIDS in Aden.

A great majority (86\%) stated that prostitution existed in society in general, and $52 \%$ had heard that prostitution existed in their area. Three-quarters of males had heard about prostitution in their area compared with only onethird of females (73\% versus 34\%) $(P<$ $0.001)$. Furthermore, there were significant differences between geographical areas, with a higher percentage of the respondents in $\mathrm{Al}$ Basateen (mainly inhabited by refugees) and Al Sesaban (mainly inhabited by marginalized citizens) aware of the existence of prostitution (69\% versus 57\%) compared with $41 \%$ in Abdul Qaui and $47 \%$ in Al Memdarah (inhabited mainly by Yemeni citizens) $(P<0.01)$.

Of the respondents, $84 \%$ thought that homosexual practices existed among society in general, while $47 \%$ 
had heard that such practices existed in their area. Male respondents were more aware of the presence of homosexual relations in the study area than were females (62\% versus 34\%) $(P<$ $0.001)$. Residents from Al Basateen and Al Sesaban were more aware of such relations (55\% each) compared with residents from Abdul Qaui (38\%) and Al Memdarah $(42 \%)(P<0.01)$.

\section{Sources of information}

Television was the main source of information about AIDS (83\%), followed by information from relatives/ friends (48\%) (Table 6). More males used radio and newspapers as sources of information than did females ( $73 \%$ versus 34\%) $(P<0.001)$. Receiving information about AIDS from relatives/ friends was also more common among males than females (60\% versus $38 \%$, $\left.\chi^{2}=27.0, P<0.001\right)(\mathrm{OR} 1.5,95 \% \mathrm{CI}$ : 1.3-1.8). Health workers were less mentioned as a source of AIDS information as were religious leaders and posters/ pamphlets.

Only 34\% had discussed HIV/ AIDS-related matters with family members, while $54 \%$ had discussed such matters with friends. Females were less likely to talk to their friends about AIDS than males (28\% versus $61 \%, P$ $<0.001$ ).

\section{Discussion}

Young people's ability to protect themselves from HIV ultimately depends on their own safe behaviour, which to a large extent, but not exclusively, depends on their knowledge about how HIV is transmitted and their perspectives on whether HIV is an issue that is directly relevant to them. [12]. Baseline knowledge, attitudes and practices studies are very useful tools prior to any interventions, to assess the extent to which an individual or a community are in a position to adopt risk-free behaviours [13].

\begin{tabular}{|c|c|c|c|c|}
\hline \multicolumn{5}{|c|}{$\begin{array}{l}\text { Table } 6 \text { Sources of information about HIV/AIDS and discussions with others } \\
\text { among young people in Aden }(n=601)\end{array}$} \\
\hline \multirow[t]{2}{*}{ Item } & \multicolumn{2}{|c|}{ Yes } & \multicolumn{2}{|c|}{ No } \\
\hline & No. & $\%$ & No. & $\%$ \\
\hline \multicolumn{5}{|c|}{$\begin{array}{l}\text { Current sources of information about } \\
\text { AIDS }\end{array}$} \\
\hline Television & 499 & 83 & - & - \\
\hline Friends/relatives & 288 & 48 & - & - \\
\hline Radio & 234 & 39 & - & - \\
\hline Newspapers ${ }^{\mathrm{a}}$ & 180 & 30 & - & - \\
\hline Schoolteachers & 175 & 29 & - & - \\
\hline Social gatherings & 138 & 23 & - & - \\
\hline Health workers & 72 & 12 & - & - \\
\hline Religious leaders & 66 & 11 & - & - \\
\hline Posters/pamphlets & 24 & 4 & & \\
\hline \multicolumn{5}{|c|}{$\begin{array}{l}\text { Preferred source of information about } \\
\text { AIDS }\end{array}$} \\
\hline Television & 532 & 89 & - & - \\
\hline Radio & 361 & 60 & - & - \\
\hline Newspapers $^{\mathrm{a}}$ & 249 & 42 & - & - \\
\hline Schoolteachers & 219 & 36 & - & - \\
\hline Health workers & 187 & 31 & - & - \\
\hline Religious leaders & 170 & 28 & - & - \\
\hline Friends & 89 & 15 & - & - \\
\hline Family & 72 & 12 & - & - \\
\hline \multicolumn{5}{|l|}{ Discussed HIV/AIDS } \\
\hline With friends & 285 & 54 & 246 & 46 \\
\hline With family members & 182 & 34 & 348 & 66 \\
\hline
\end{tabular}

${ }^{a}$ Literate respondents only.

$n=$ total sample; data are missing for some items.

Before discussing the findings of this study we would like to mention some limitations. Discussions on sexual matters and issues related to HIV/AIDS are taboo in Yemen and therefore some difficulties were faced during the interviewing process. We were unable to ask some direct questions about personal behaviours which would have been important to know. In some cases, and despite repeated assurance by the data collectors, mothers did not allow the interviewers to interview their children alone, especially females, and their presence may have influenced the response to certain questions. The fieldwork was also conducted after some health education activities had been conducted by national and international nongovernmental organizations in the study areas which may have led to higher levels of awareness than expected. Last but not least, the final stage of sampling that involved putting criteria for selection of interviewees when there were more than 2 eligible persons, led to inclusion of a higher parentage of females in the older age group.

Nevertheless, the findings of this study are still important as it is the first published study about young people's awareness and attitude in high-risk areas in Yemen. The study shows that young people lacked proper information about HIV/AIDS. Although 89\% had heard of AIDS, only $46 \%$ could name 3 ways of transmission and only $28 \%$ could name 3 ways to avoid infection. A major United Nations study found "an alarming lack of knowledge about 
HIV/AIDS" among young people and that they did not have the proper knowledge to protect themselves. In Ukraine, for example, although $99 \%$ of girls had heard of AIDS, only $9 \%$ could name 3 ways to avoid infection [2].

Misconceptions about how HIV/ AIDS is transmitted reveal that young people are not getting access to the right information. Our study showed that misconceptions about modes of transmissions, e.g. touching, eating or drinking, contact with clothes, kissing and insect bites, were widely prevalent. This issue was also addressed by previous research among the general population in Yemen [14] and neighbouring Arab countries [15]. According to UNICEF "surveys from 60 countries indicated that more than $50 \%$ of young people aged 15 to 24 years had serious misconceptions about how HIV/AIDS is transmitted" [2]. Therefore, providing information about HIV/AIDS transmission that emphasizes the lack of scientific evidence for these beliefs should be a priority for any future information, education and communication campaigns about HIV/AIDS.

In this study there were negative attitudes among the participants towards AIDS patients. There was a common opinion that AIDS patients needed to be isolated (if not jailed or even killed) and that, even when given medical care, they should receive specialized care in special health settings. About threequarters of the respondents stated that they were not willing to buy groceries from a person who had AIDS and that a teacher who was infected with AIDS should not continue teaching. Such attitudinal problems were found among young people from other similar developing countries, for example, the Islamic Republic of Iran [16] and India [17]. Such serious attitudinal problems and widespread misconceptions caused by lack of education about AIDS need to be addressed.
Denial about the risk of AIDS is widespread even when there is knowledge about the disease. Studies show that many young people who are sexually active and know the modes of transmission of the virus report that they face little or no risk of becoming HIV-positive themselves; for example, according to UNICEF, as many as $87 \%$ of 15-19-year-olds did not believe themselves to be at risk [2]. The findings of our study showed that $28 \%$ of the young people interviewed believed that there was no possibility that they could get infected. A situation analysis among Yemen AIDS patients found that no patient believed that he/she could be a victim of HIV/AIDS [5]. Respondents' good awareness of links between the risk of AIDS and extramarital sex - and to a lesserextenthomosexuality - ispositive and needs to be encouraged, especially as the study findings show that such risky behaviours may be common in the study areas. However, as many of the participants stressed that they did not need to make any behavioural changes themselves - as they were conservative and not doing "bad" things - the fact needs to be emphasized that avoiding extramarital sex or homosexuality do not confer $100 \%$ protection from HIV/ AIDS and that it still could be transmitted by other means (e.g. through health care settings).

This study confirms previous research findings from Yemen that television is the current and probably the future leading source knowledge about HIV/AIDS [13]. The fact that television is one of the few sources of information that is used equally by both males and females is also important as it can be used to minimize the significant gender gap in knowledge that was underlined by this study. The fact that schoolteachers were mentioned as a current as well as a future preferred source of knowledge about HIV /AIDS is promising. Education is one of our most important weapons against the spread of HIV/AIDS. The evidence for this is growing; in countries with severe epidemics, young people with higher levels of education are more likely to use condoms and less likely to engage in casual sex than their less-educated peers [18]. We need to educate children and young people about HIV/AIDS and teach them skills that translate this knowledge into action. Therefore this opportunity should not be missed and schools should be used as a hub for such prevention lessons.

Last but not least, the finding that about half of the young people knew that prostitution and homosexuality existed in their area, albeit with a significant gender and geographical difference, is concerning and needs future attention. It supports previous anecdotal reports about these areas. Al Basateen (inhabited by refugees) and Al Sesaban (inhabited by marginalized populations) are characterized as high risk due to the large numbers of commercial sex workers living there, and they represent transit hubs for migrant populations coming from the Horn of Africa, where HIV/AIDS prevalence is higher than in Yemen [9].

Based on these findings, certain recommendations can be made. As the prevention of the spread of HIV infection is a priority in Yemen [8] and one of its Millennium Development Goals [4], the findings of this study should help policy-makers and health care professionals to develop a culturally sensitive and needs-specific educational programme for Yemeni young people. Settings such as Yemen which have low HIV/AIDS prevalence must be prepared to act concurrently at 3 key levels of interventions-advocacy, information and knowledge-in order to keep the prevalence rates low. An enabling environment within which these interventions can take place is essential. Advocacy to raise the awareness of young people regarding the issues of HIV/AIDS and reduce the stigma 
associated with the disease is vital for achieving this. Youth-friendly services, especially for marginalized and refugee groups, that provide adequate reproductive health care information are essential. Such services have the ability to attract young people, meet their needs comfortably and responsively, and succeed in retaining these young clients for continuing care.
More research on young people's HIV/AIDS knowledge, attitudes and beliefs needs to be done in Yemen. Similar investigations should be repeated to provide insights about how behaviour and knowledge are altered in the study areas in relation to any future HIV/AIDS information and education campaigns.

\section{Acknowledgements}

We would like to sincerely thank the fieldworkers and supervisors. We are grateful to all the young people who cooperated and participated in making this study a reality. The work was supported by a grant from HIV/AIDS UNICEF and implemented by SOUL for the Development of Women and Children.

\section{References}

1. HIV/AIDS and work: global estimates, impact on children and youth, and response. Geneva, International Labour Organization, 2006

2. Young people and HIV/AIDS: opportunity in crisis. New York, United Nations Children's Fund, 2002 (http://www.unicef org/publications/index_4447.html, accessed 3 August 2009).

3. UNGASS AIDS 2006 review. Youth summit message. United National Children's Fund [online document] (http://www.unicef. org/voy/media/UNGASS_2006_Review_Youth_Msg.pdf, accessed 31 August 2009).

4. MDG: needs assessment. Health and population. Sana'a, Yemen, Health and Population Core Team, Ministry of Public Health and Population, 2005

5. HIV/AIDS situation and needs assessment report. Sana'a, Yemen, United Nations Development Programme, 2001.

6. Busulwa R. HIV/AIDS situation analysis study, conducted in Hodeidah, Taiz, Aden and Hadhramut, Republic of Yemen. Sana'a Yemen, United Nations Development Programme/World Health Organization/National AIDS Program, Ministry of Health and Population, 2003.

7. National strategic framework for the control and prevention of HIV/AIDS in the Republic of Yemen. Sana'a, Yemen, Ministry of Public Health and Population, 2002.

8. Al-Rabee' A. Adolescent and youth reproductive health in Yemen: status, policies, programs, and issues. Washington DC, Futures Group International, 2003.

9. Al Ahmadi A, Beatty S. Participatory socioeconomic needs survey of the Sana'a urban settlements dwellers with special reference to women. Yemen, Oxfam, 1997.

10. Yemen: stigma, ignorance hampering fight against HIV-AIDS IRIN HIV/AIDS (PlusNews) [online press release] (http://www. irinnews.org/report.aspx? reportid=25764 12, accessed 3 August 2009).

11. Multiple indicator cluster surveys-round 3. New York, United Nations Children's Fund, 2005 (http://www.childinfo.org/ mics3.html, accessed 3 August 2009).

12. Epidemiological fact sheets on HIV/AIDS and sexually transmitted infections. Yemen, Joint United Nations Programme on HIV/ AIDS, 2004.

13. National AIDS programmes: a guide to monitoring and evaluation. Geneva, Joint United Nations Programme on HIV/AIDS/ World Health Organization/MEASURE Evaluation Project, 2000 (UNAIDS/00.17).

14. Al-Serouri AW et al. Knowledge, attitudes and beliefs about HIV/AIDS in Sana'a, Republic of Yemen. Eastern Mediterranean health journal, 2002, 8(6):706-15.

15. Al-Owish R et al. Knowledge, attitudes, beliefs and practice about HIV/AIDS in Kuwait. AIDS education and prevention, 1999, 11(2):163-73.

16. Tavoosi A et al. Knowledge and attitude towards HIV/AIDS among Iranian students. BMC public health, 2004, 4:17.

17. Agrawal HK et al. Knowledge of and attitude to HIV/AIDS of senior secondary school pupils and trainee teachers in Udupi District, Karnataka, India. Annals of tropical paediatrics, 1999, 19:143-9.

18. School education to prevent AIDS and sexually transmitted diseases. Geneva, World Health Organization, 1992 (AIDS Series No 10). 